\title{
Class, Classical, and Consensus Views of the Constitution
}

\author{
John Patrick Diggins $\dagger$
}

An Economic Interpretation of the Constitution of the United States. Charles A. Beard. With a new introduction by Forrest McDonald. Originally published 1913; author's introduction added 1935. The Free Press, New York, New York, 1986. Pp. liii, 327. \$10.95 (paper).

On Revolution. Hannah Arendt. Originally published 1963. Pelican Viking ed., New York, New York, 1987. Pp. 350. $\$ 7.95$ (paper).

The Liberal Tradition in America. Louis Hartz. Originally published 1955. Harcourt Brace Jovanovich, New York, New York, 1983. Pp. ix, 329. $\$ 8.95$ (paper).

With the current bicentennial celebrating the Constitution as the nation's greatest political success story, it may seem a little unpatriotic to write about three authors who judged it, if not a failure, something less than a fulfillment. Charles Beard, Hannah Arendt, and Louis Hartz had some perceptive things to say about what had happened in Philadelphia in 1787, and each concluded that the American founding was ill-founded. Even though all three admired the framers, each had reasons for believing things would have been better had the framers thought differently about liberty and power. And each scholar read into the American past his or her own ideological predilections. With Beard it was class realities, with Arendt classical ideals, and with Hartz deeper consensual structures. Thus, each author had different reasons for being ambivalent about the Constitution.

Beard's An Economic Interpretation of the Constitution remains one of the most provocative and controversial books ever written by an American historian. Prior to Beard's Progressive era the Constitution's authority rested on the assumption that it was a

$\dagger$ Professor of History, University of California, Irvine. 
neutral document rendering objective judgments based on either transcendent religious principles or secular doctrines like natural law. Although later generations enshrined the Constitution as a semi-divine document, the framers described it as deriving not from abstract theory but from a history of human experience with political power, economic interests, and social relations. The framers, in short, were not idealists who sought to judge history from some standard external to history itself. Instead, they were realists who viewed the issues of history as reducible to questions of power and how to control it. Why, then, did Beard not esteem their Constitution as worthy of the status of genuine authority? Clearly the document was grounded in the reality of everyday experience, which for pragmatists, as well as Marxists, is the criterion of truth. What was Beard's quarrel with the Constitution?

Basically there are three dimensions to Beard's thesis: (a) the economic, involving the monetary and property interests at stake in framing the Constitution; (b) the political, involving the procedure by which the Constitution was adopted and power relocated in the new federal government; and (c) the intellectual, involving the use of ideas to explain and justify the new Constitution in order to legitimate it and persuade the people to accept its authority.

The Constitution, Beard argued, was essentially an "economic document." Rather than being drafted by high-minded men dedicated to such abstract ideals as "justice," "liberty," and "the pursuit of happiness"-the conventional wisdom-the Constitution was devised by consolidated economic groups who had dealt in money, public securities, manufacturing, or trade and shipping. These groups played a decisive role in the decision to scuttle the older Articles of Confederation. Moreover, they dominated the ratifying conventions in the states.

The opposition to the Constitution consisted of small farmers and debtors whose meager resources were tied to land and whose interests and demands had been effectively reflected under the Confederation. Having obtained control of currency and commerce in the states, the anti-Federalists claimed that those who wanted to transfer such powers to the new federal government under the proposed Constitution were aristocrats attempting to establish government to benefit only the wealthy few.

Politically the Constitution represented an extra-legal coup d'etat. Democratic mythology depicted the Constitution as proceeding "from the whole people; the people are the original source 
of all political authority exercised under it." But the new government, according to Beard, was actually put over by undemocratic means and imposed on a society where democracy had yet to be born. Property qualifications for voting and office holding excluded "a large propertyless mass," and hence probably not more than one-sixth of the adult male population ratified the Constitution, and in five states it was questionable whether a majority of voters even approved of ratification. The unenfranchised and unrepresented small farmers and debtors thus lost power under the new system, not only because they had no effective voice in the outcome of the debates, but also because the new centralized government now possessed the economic liberties the states once enjoyed, specifically the right to print money and dissolve contract obligations. Hence, the Constitution dramatized "the concept that the fundamental private rights of property are anterior to government and morally beyond the reach of popular majorities."2

An economic movement and a political maneuver required an intellectual rationale, an ideological function that James Madison fulfilled with consummate skill. Beard emphasized that his book derived not only from archival research into the Treasury Department but also from a close reading of Madison's political philosophy in the Federalist, especially paper number 10 . That key document, a "masterly statement of the theory of economic determinism," offered an analysis of why the unequal division of property leads to "class" and "group" divisions and why politics and law "inevitably" reflect these contending interests. Madison made the control and regulation of these "factions" the "first object" of government." The Constitution was designed not to fulfill the egalitarian principles of the Declaration of Independence but to regulate conflict through a maze of checks and balances among the departments of government and a division of powers between the federal government and the states. ${ }^{5}$

When Beard's Economic Interpretation first appeared in 1913, the academic response was on the whole "quite favorable," but non-academics greeted it with howls of outrage. ${ }^{6}$ The more discern-

2 Charles A. Beard, An Economic Interpretation of the Constitution of the United States 10 (1935).

2 Id. at 324-25.

Id. at 15.

- Federalist 10, in Clinton Rossiter, ed., The Federalist Papers 77, 78 (1961).

s Beard, Economic Interpretation at 15-16 (cited in note 1).

- Richard Hofstadter, The Progressive Historians: Turner, Beard, Parrington 212 (1968). 
ing scholars, like Oliver Wendel Holmes, Jr., responded to Beard's thesis with almost a yawn. Holmes took for granted economic interest in all political activity, and he saw law as little more than its implementation through force. However, reaction changed over time. Some years later Walter Lippmann responded implicitly to the Beard thesis by observing that the framers, rather than creating the Constitution to protect property, used their "class privileges" to preserve their country. ${ }^{7}$ In more recent times, historians have challenged Beard's thesis by arguing that the conflict between the Federalists and anti-Federalists was not a class struggle but a division between provincial farmers and cosmopolitan merchants, that the framers may have desired to control democracy yet still affirmed that government rests on the consent of the governed, and that they were primarily interested in unionism and a strong nation state. Nevertheless, a number of Beardian arguments remain that are less easy to refute: (a) that liberty and property were in conflict to the extent that the Constitution was designed to protect minority interests from popular majorities-which Madison described as "overbearing;" (b) that Madison was indeed an economic determinist and that he, Hamilton, and John Adams did see in the formation of "factions" an expression of class struggle between the many and the few; and, therefore, (c) that the Constitution did violate, at least implicitly, the Declaration to the extent that the older Lockean principle of the will of the majority was not to be allowed to express itself collectively through political means. ${ }^{8}$

Whether or not Beard's arguments are valid, he did not come to hate the proponents of the Constitution and love its opponents. Although the Progressive school of history associated with Vernon L. Parrington tended to identify Beard as a Jeffersonian who esteemed the anti-Federalists as genuine democrats dedicated to political ideals rather than economic interests, Beard saw the antiFederalists as motivated by property concerns as much as the Federalists. Moreover, he ridiculed Jefferson's idolization of "the people" and refused to worship the Declaration as sacrosanct. He also challenged the Progressive criticism of judicial review and believed that the Supreme Court provided a vital check on democratic state legislatures. In addition, he admired the Federalists for recognizing the inadequacies of the Articles of Confederation; and in The Eco-

7 Walter Lippman, Public Opinion 280 (1922).

${ }^{8}$ See John Patrick Diggins, Power and Authority in American History: The Case of Charles A. Beard and His Critics, 86 Am.Hist.Rev. 701, 713 (1981). 
nomic Origins of Jeffersonian Democracy ${ }^{9}$ and elsewhere, he praised the political insights of John Adams and the economic foresights of Alexander Hamilton. ${ }^{10}$

Beard's quarrel was not with the framers, who had a firm grasp of the "conflicts of economic interests" surrounding the Constitution's ratification, a point he made in his 1935 "Introduction" to An Economic Interpretation. ${ }^{11}$ His quarrel was directed at nineteenth century historians who had sanctified the Constitution by hailing the triumph of supposedly high-minded nationalists over the "narrow" advocates of state rights. But if Beard admired the Federalists as intellectuals, he retained a sentimental nostalgia for the anti-Federalists. Sometimes he depicted the Constitution's opponents as forerunners of late nineteenth century populists. Beard described the anti-Federalist author "Centinel" as "the warmest advocate of the initiative and referendum in our time."12 "Under the Articles of Confederation populism had a free hand, for majorities in the state legislatures were omnipotent."13 Long after he had written An Economic Interpretation, Beard continued to regard the state legislatures of the Revolutionary era as animated by an advanced agrarian radicalism. The Revolution made "the local legislatures, in which farmers had the majorities, supreme over all things," and there "the leveling tendencies" reflected the egalitarian spirit of the Declaration. ${ }^{14}$ It could be said that for Beard the Constitution did more to flout the Revolution than to fulfill it.

Hannah Arendt's reasoning about the Revolution and Constitution is somewhat similar yet far more complex and ambiguous. "Paradoxical as it may sound," she wrote in On Revolution, "it was in fact under the impact of the Revolution that the revolutionary spirit in this country began to wither away, and it was the Constitution itself, this greatest achievement of the American people, which eventually cheated them of their proudest possession."15 How could the American people both incorporate the revolutionary

- Charles A. Beard, The Economic Origins of Jeffersonian Democracy 299-321 (on John Adams), 112-131 (on Alexander Hamilton) (1952).

10 See the valuable reinterpretation by Pope McCorkele, The Historian as Intellectual: Charles Beard and the Constitution Reconsidered, 28 Am.J.Leg.Hist. 314, especially at 32141 (1984).

11 Beard, Economic Interpretation at vii (cited in note 1).

12 Id. at 313.

13 Charles A. Beard, The Supreme Court and the Constitution 88 (1962).

14 Charles A. Beard and Mary R. Beard, 1 The Rise of American Civilization 299, 307 (1927).

1s Hannah Arendt, On Revolution 242 (1963). Page references in this and subsequent notes are to the original edition, rather than to the newly issued Pelican reprint. 
spirit into the Constitution and then allow it to become their "lost treasure"?

Arendt mentions Beard only once in On Revolution, primarily to chide American historians for trying to unmask the founders as hypocrites who spoke the language of liberty while proceeding to defend property. ${ }^{16}$ In contrast to Progressive historians, Arendt avoids dramatizing the alleged discrepancy between the liberty-oriented Declaration and the property-oriented Constitution, and she denies that what took place at the Philadelphia Convention was a "counter-revolution." Both the idea of liberty and the idea of property pertain to individuals, and Arendt is primarily concerned with power, which she views as a collective phenomenon that "comes into being only if and when men join themselves together for the purpose of action."17 After the Revolution, when the authority of the Crown and Parliament had been abolished, there developed something of a power vacuum in the colonies, and the aim of various state legislatures in writing new constitutions was to create new centers of power. So far, so good. But why did it become necessary to take power from the state legislatures and relocate it in the new federal government proposed by the Constitution?

Curiously, Arendt says very little about the social and economic tensions that erupted during the period between the Revolution and the Constitution that some historians refer to as "the critical era." The tariff barriers among the states and their non-interchangeable currency systems, the growing antagonisms between urban creditors and rural debtors who tried to pay off their loans by forcing the respective legislatures to issue more money, the armed uprising of desperate farmers in western Massachusetts-the very problems and events that worried Adams, Madison, and Washington-gave Arendt little cause for concern. Perhaps this was because Arendt had already attributed the success of the Revolution to the claim that America, unlike France and other countries, did not have to address "the social question," that is, the issue of poverty and misery-the solution to which presumably caused other revolutions to escalate beyond their original goals and in the process destroy their original ideals. ${ }^{18}$ Whether or not the American Revolution was strictly a political event that did not have to address the social question, Arendt explains the Constitution not through an historian's description of tensions but

${ }^{16}$ Id. at $94-95$.

17 Id. at 174.

${ }^{18}$ Id. at $62-63$. 
through a philosopher's definition of terms.

Unlike Beard and even some contemporary "neo-progressive" historians such as Gary Nash and, in some respects, Gordon Wood, Arendt views the Constitution as "the true culmination of this revolutionary process." Those who see the Constitution as a product of the "forces of reaction" fail to see the inherent logic of a revolution. "The basic misunderstanding lies in the failure to distinguish between liberation and freedom; there is nothing more futile than rebellion and liberation unless they are followed by the constitution of the newly won freedom."19 While rebellion aims toward liberation, the end of revolution must be the foundation of freedom. In rebelling against England the colonists sought to eliminate an alien government, but after the Revolution the question of power still remained. "When they declared their independence from this government, and after they had forsworn their allegiance to the crown, the main question for them certainly was not how to limit power but how to establish it, not how to limit government but how to found a new one."20 The founders drew upon Montesquieu for theories on the separation of the branches of the government in order to secure freedom by dispersing power. And freedom is established by allowing power to be augmented and arrested at the same time, that is, deposited in the new central government where it can be both exercised and controlled. Arendt quotes Adam's dictum that "power must be opposed to power, force to force, strength to strength" in order to make the point that the Federalists were not trying to centralize all power in the new government. ${ }^{21}$ Instead, they were attempting to overcome the impotence of the Articles of Confederation while at the same time assuring that there would remain no single source of power that would function as sovereign authority.

Moreover, according to Arendt, the founders learned from the Romans that while power resides in the people, authority resides in the Senate. This strategic division was made even more effective by Hamilton. He completely separated power from authority, the popular will from judicial wisdom, by investing "the majesty of national authority" in the Supreme Court, an institution that had "neither force nor Will," in Hamilton's words, and was therefore the "weakest" of the three branches of government. ${ }^{22}$

22 Id. 200-01. 
Arendt marvels at all these devices that emerged from the Constitutional Convention. She recognizes that they had antecedents in both classical antiquity and the modern Enlightenment. Yet the American Constitution represented a profound breakthrough in western political philosophy. "In this respect, the great and, in the long run, perhaps the greatest American innovation in politics as such was the consistent abolition of sovereignty within the body politic of the republic, the insight that in the realm of human affairs sovereignty and tyranny are the same."23

Charles Beard also recognized that the framers had successfully abolished the idea of sovereignty in the Constitution, but he interpreted their reasons for doing so entirely differently. He quoted Madison's Federalist 10 to show why the framers feared sovereignty as the will of the majority acting in concert-Arendt's definition of power. "Whilst all authority in it will be derived from and dependent on the society," Madison wrote in reference to the new republic, "the society itself will be broken into so many parts, interests, and classes of citizens, that the rights of individuals, or of the minority, will be in little danger from the interested combination of the majority."24 To Beard, such a scheme could only mean that the activity of popular majorities would be frustrated while the activity of economic interests that move under the sanctity of law would be protected:

If we examine carefully the delicate instrument by which the framers sought to check certain kinds of positive action that might be advocated to the detriment of established and acquired rights, we cannot help marvelling at their skill. Their leading idea was to break up the attacking forces at the starting point: the source of political authority for the several branches of government. This disintegration of positive action at the source was further facilitated by the differentiation in the terms given to the respective departments of the government. And the crowning counterweight to "an interested and over-bearing majority," as Madison phrased it, was secured in the peculiar position assigned to the judiciary, and the use of the sanctity and mystery of the law as a foil to democratic attacks. 25

Both Arendt and Beard perceived that the Constitution had

\footnotetext{
${ }^{23}$ Id. at 152.

24 Federalist 51, in The Federalist Papers at 320, 324 (cited in note 4).

${ }^{25}$ Beard, Economic Interpretation at 161 (cited in note 1).
} 
abolished the idea of sovereignty. The former believed the framers did so because they feared tyranny, the latter because they feared democracy. A thinker like John Adams, who coined the phrase "democratic despotism" a half century before Tocqueville, would most likely have seen no distinction between tyranny and democracy. It should also be noted that among the most original contributions of the framers was not only their abolishing sovereignty but their role as the first philosophers in western political thought to identify liberty with diversity. Whereas Rousseau had identified liberty with the unanimity of the "general will," Madison and Adams denied that all power could be invested in a single entity such as a national assembly that presumably would represent all the people. Whereas the entire classical tradition, extending from Aristotle to Machiavelli to Montesquieu, had insisted that the purpose of politics was to transcend the differences among interest groups, the Federalists recognized those differences as permanent, natural, and unalterable. "Liberty is to faction what air is to fire," advised Madison in Federalist 10, "an aliment without which it instantly expires." ${ }^{23}$ Adams in particular would have had difficulty understanding what Arendt meant when she claimed that the framers saw the lower house of Congress as the springboard of power and the Senate as the source of authority. Adams viewed the "rich, well-born, and able" as just as exploitive as any other group, and thus they were to be isolated (the tactic of "ostracism") in the upper house so they could not prey upon the less able members of the lower. Adams did not juxtapose authority to power but power to power.

Arendt remained convinced emphatically, and Beard implicitly, that the Constitution had sapped the emancipatory spirit of the Revolution that supposedly manifested itself during the period of the Articles of Confederation. Arendt in particular assumed that mass democratic participation prevailed during and after the Revolution. It was only with the coming of the Constitution and the new Republic that Americans lost sight of the public space necessary for the continuous exercise of freedom, those qualities of deliberation and action that had been required for the construction of government itself. Equating the faculty of human freedom with the ability to begin and inaugurate, Arendt observed in small, spontaneous revolutionary activity the area in which the public realm is founded as human beings interact with one another and

26 Federalist 10 , in The Federalist Papers at 78 (cited in note 4). 
accept the authority of the founding. She believed she could see this phenomenon taking place in America's town meetings in 1775, in Russia's councils and soviets in 1917, and in Hungary's räte in 1956. But the spirit of the American Revolution failed to find its appropriate institution in the Constitution, which was more concerned, as Beard had emphasized earlier, with protecting private interest rather than promoting the public good, with controlling democracy rather than expressing it.

A student of Max Weber might point out to Arendt and her followers that a revolution is by nature a "movement" that sooner or later must yield to the necessity of organization and control. Yet Arendt believed that she had found in Jefferson's teachings the formula for revolutionary revitalization. Unlike the framers of the Constitution, Jefferson was not troubled by the Shays uprising. Like Thomas Paine, Jefferson believed America had the power "to begin the world over again," and the Shaysites were merely assuring that the Revolution could be repeated in action so that its significance would not be lost to memory. "God forbid," Jefferson exclaimed, "we should ever be twenty years without such a rebellion."27 Jefferson's and Paine's conviction that the tree of liberty must be periodically "bathed" in the blood of rebellion, that the earth belongs to the living, and that each generation is sovereign and cannot be governed by the dead hand of the past seemed evidence to Arendt that America had found the key to permanent revolutionary struggle. She was particularly impressed with Jefferson's citation to Cato's injunction: "divide the country into wards." She acknowledges that there is no mention of the ward system in any of Jefferson's formal writings or speeches. Nevertheless, from a smattering of private letters Arendt believes she can establish Jefferson as the philosopher of freedom identified as a continuous reenactment of the founding at the most local level of political activity:

Jefferson himself knew well enough that what he proposed as the "salvation of the republic" actually was the salvation of the revolutionary spirit through the republic. His expositions of the ward system always began with a reminder of how "the vigor given to our revolution in its commencement" was due to the "little republics," how they had "thrown the whole nation into energetic action," and how, at a later occasion, he had felt "the foundations of government shaken under [his]

${ }^{27}$ Arendt, On Revolution at 236 (cited in note 15). 
feet by the New England townships," "the energy of this organization" being so great that "there was not an individual in the States whose body was not thrown with all its momentum into action." Hence, he expected the wards to permit the citizens to continue to do what they had been able to do during the years of revolution, namely, to act on their own and thus to participate in public business as it was being transacted from day to day. By virtue of the Constitution, the public business of the nation as a whole had been transferred to Washington and was being transacted by the federal government, of which Jefferson still thought as "the foreign branch" of the republic, whose domestic affairs were taken care of by the state governments. ${ }^{28}$

Having identified politics as the only realm of freedom, and having defined freedom as a quality found only in action, and public action at that, Arendt proceeds to assess the validity of Jefferson's teachings on the basis of what he conveyed privately in correspondence. Arendt fails to distinguish Jefferson the philosopher from Jefferson the Statesman, man of thought from man of action. The philosopher, it is true, wanted to preserve the values of rural life and to continue the ward system in the name of Republican simplicity, restrict the power of the national government in the interest of human liberty, and uphold the principle of state sovereignty as the best guardian of the will of the majority. The philosopher also distrusted the power of the executive and Supreme Court, and he called for a reduction in taxes and elimination of the tariff and the Bank of the United States. Jefferson the President, however, violated his own principles in allowing the old Federalist banking system to remain and the debt to increase, in failing to revise the Judiciary Act, and most of all in negotiating the Louisiana Purchase with the advice and consent of neither Congress nor the states-a move that boldly expanded executive power, negated the philosopher's own strict construction of the Constitution, and assured that America would be a large, continental empire in which the precious little ward system would be more irrelevant than ever. ${ }^{29}$

Aside from the disparity between Jeffersonian theory and practice, there remains a utopian assumption at the basis of both

28 Id. at 254.

20 Still the greatest scholar on this subject is Henry Adams. See his magisterial History of the United States of America During the Administration of Thomas Jefferson (1889-91). 
Arendt's conviction that the Constitution thwarted the spontaneous spirit of the Revolution and Beard's conviction that the Constitution deflected the emancipatory ethos of the Declaration. That is the assumption that the anti-Federalists, Jeffersonians, followers of Paine and Shays, and others who supposedly held out for an "elementary Republic" were more democratic and egalitarian, more disposed to participate in civic activity, and more dedicated to the public good. Yet we know, thanks to the research of Cecelia Kenyon, that the anti-Federalists themselves were "men of little faith," that it was the opponents of ratification who were so distrustful of fellow man that they believed the Constitution needed more, not fewer, checks in order to control the power of the central government. ${ }^{30}$

What, then, of local government? It is here, in the state legislatures and town meetings, that Arendt claimed to have seen the flowering of agrarian populism and participatory democracy. Yet those who wanted to preserve the Articles of Confederation were not necessarily pining for the intimacy of local wards and community politics. They feared the consolidation of power in the central government as a threat to their economic well-being. The anti-Federalists, to be sure, worried about executive corruption and usurpation, and many doubted that the Constitution's mosaic of checks and balances would render power safe and leave secure republican forms of government in the states. And no doubt their lasting contribution to America's political culture was their insistence that the Constitution include a Bill of Rights.

But that demand had more to do with preserving what Isaiah Berlin has called "negative" liberty, rather than "positive" liberty. $^{31}$ The anti-Federalists were less interested in securing the ability to participate in government than in the power to resist it. What they wanted to resist would surely warm the cockles of Ronald Reagan's heart. "I know there are politicians who believe you should be loaded with taxes, in order to make you more industrious," wrote the pseudonymous "Cato." "[B]ut it is an erroneous principle. For what can inspire you with industry if the greatest measure of your labor are to be swallowed up in taxes?"32 Even the

${ }^{30}$ Cecelia M. Kenyon, Men of Little Faith: The Anti-Federalists on the Nature of Representative Government, $12 \mathrm{Wm}$. \& Mary Q. 3, 42-43 (1955).

${ }^{31}$ Isaiah Berlin, Four Essays on Liberty 118-72 (1969).

${ }^{32}$ W.B. Allen and Gordon Lloyd, eds., The Essential Antifederalists 159, 163 (1985). For another view denying that the opponents of the Constitution were classical republicans devoted to civic virtue and the public good, see Herbert J. Storing, What the Anti-Federalists Were For (1981). 
Virginian anti-Federalists who demanded the Bill of Rights, George Mason and Patrick Henry, feared the new Constitution would allow the North to predominate and threaten not only state sovereignty but black slavery.

In the supplanting of the Constitution with local wards, Arendt believed she could find the basis of freedom in a polity that had only solved the problem of power. "The basic assumption of the ward system, whether Jefferson knew it or not, was that no one could be called happy without his share in public happiness, that no one could be called free without his experience in public freedom, and that no one could be called either happy or free without participating, and having a share, in public power."ss Actually there is no mention of the "public" at all in Jefferson's discussion of wards. "Every State again is divided into counties, each to take care of what lies within its local bounds; each county again into townships or wards, to manage minuter details; and every ward into farms, to be governed each by its individual proprietor. Were we directed from Washington when to sow, and when to reap, we should soon want bread."34 Instead of defining freedom as the ability to participate in the noble life of politics, Jefferson identified it as the autonomous individual growing his own crops and managing his own affairs.

Ironically, Arendt's definition of freedom as having its birth in the spontaneity of local, collective activity was precisely what the Federalist authors sought to suppress. Hamilton and Madison believed that the "tempestuous" disturbances and "convulsions" in certain state legislatures made a new Constitution all the more urgent. $^{35}$ They assumed that they could secure liberty not only by institutionalizing political power but also by controlling class conflict. It is the genius of Louis Hartz that showed us why the framers were right for the wrong reasons and why they gave us a Constitution that worked despite their misguided intentions. ${ }^{36}$

Hartz's The Liberal Tradition in America represents the last successful attempt to write a synthesis of American history in order to establish the foundations of America's political culture. Much of Hartz's analysis derives from Tocqueville's insight that Americans were "born equal" and did not have to struggle against

ss Arendt, On Revolution at 258-259 (cited in note 15).

34 H. A. Washington, ed., 1 The Writings of Thomas Jefferson 82 (1853).

35 Federalist 21, in The Federalist Papers at 138, 140 (cited in note 4).

36 The following account is more fully developed in my essay, Knowledge and Sorrow: Louis Hartz's Quarrel With American History, -- Pol.Theory - (forthcoming). 
class structure to become so. Starting from that premise, Hartz offers a two-fold explanation to account for the enduring ethos of liberalism: the absence of feudalism and the presence of Lockeanism. The first condition meant that America had no aristocracy that as a class would have resisted social change, denigrated the value of labor, and ridiculed the idea of equality. The second condition meant that Americans would be property conscious, value individual natural rights even if they were more sensed than understood, and regard liberty as consisting more in resistance to authority than in the classical duty of participating actively in the workings of government. Such conditions produced a mentality that precluded the possibility that America would have either a reactionary aristocracy or a-revolutionary working class. America, in short, was and will always be different, unique, anomalous-what the Old Left used to call the problem of "exceptionalism."

Two awkward realities confronted Hartz. For one thing, except for Tocqueville, few thinkers could be cited to support his thesis. Neoclassical scholars like Arendt were more fond of finding analogues to America in the Old World, even in classical antiquity; and Beard, according to Hartz, was so caught up in European class categories that he failed to explain America to itself. But the second reality facing Hartz was even more embarrassing. If liberalism was the underlying theme of America, why did not the framers see it? Or, to be more precise, why did they glimpse it and then lose sight of it?

The first two chapters of The Liberal Tradition deal with the Revolution and Constitution. Ironically, in the first episode American political thinkers saw their country as an exceptional experience and in the second as a general phenomenon. Hartz quotes John and Samuel Adams, Gouverneur Morris, and others to convey the conviction that the Revolution of 1776 was unique and incapable of being emulated by France and the Old World. Among its unique properties was the combined fact that America did not have to "endure a democratic revolution"37 (Tocqueville's expression), had the church as an ally and hence had no need to develop a political religion à la Rousseau, ${ }^{38}$ enjoyed an environment in which long-known material satisfactions outweighed the momentary political grievances with England, ${ }^{39}$ escaped the need to cen-

${ }^{37}$ Louis Hartz, The Liberal Tradition in America 38 (1955).

38 Id. at $40-41$.

${ }^{39}$ Id. at $47-48$. 
tralize political authority since there was no ancien regime to destroy, ${ }^{40}$ and managed to pull it all off without the appearance of the great legislator, the "classical giant," whose traditional role of showing up at the right moment to lay the foundations of political freedom could be by-passed since the foundations had been lain at the dawn of colonial life. ${ }^{11}$ The American Revolution also produced a "victorious middle class" that was not class conscious since, unlike the French bourgeoisie, it did not have to struggle to overcome such feudal residues as guild restriction and parasitical privileges. As a result, Americans felt no need to establish physiocratic controls over the economy. Instead they became Lockeans, not in the intellectual sense that each and every American had read the philosopher's political treatises, but in the cultural sense of remaining distrustful of all authority that did not come from themselves, valuing natural rights and the rewards of labor, and being convinced that the power of the state must be limited. Clearly, the "pursuit of happiness" had a private connotation and not, as Arendt insisted, a "public" meaning. Taken directly from Locke, it implied for Jefferson the right to enjoy family and farm and through productive activity improve one's property free of the encroachments of state and society. ${ }^{42}$

Yet while the revolutionary experience may have depicted America as free from European social categories and political theories, the Constitution represented, to Hartz's dismay, a return to Old World modes of thought. In part, this reversal of perspectives resulted from the class tensions that broke out in Massachusetts, Rhode Island, and elsewhere during the post-revolutionary "critical era" (1783-87). With popular protests against foreclosures and demands that state legislatures issue stay laws and inflated currency to protect indebted farmers, it seemed that the American revolution had indeed a volatile social content. Some Americans began to look upon Daniel Shays' uprising as the prototype of Gracchus Babeuf's movement in France, an assault not only on aristocracy but on wealth, property, and all social distinctions that separated man from fellow man. Ignoring Charles Pickney's warning that America was not Europe, Federalists such as Madison and John Adams adopted "a Hobbesian view of man" and wrote of human nature as though it were a universal constant, saw the spectre of "aristocrats" and "levellers" everywhere and assumed they

12 Id. at $49-53$. 
posed a threat to the few. ${ }^{43}$ Thus, they went to Philadelphia to write a Constitution for a society seething with class conflict. The class fears of the Federalists left Hartz as amused as he was appalled. "The Founding Fathers devised a scheme to deal with conflict that could only survive in a land of solidarity. The truth is, their conclusions were 'right' only because their premises were wrong." 44

Hartz' thesis that the framers were thinking about class-ridden European society when they drafted the Constitution and, as a result, the new federal system of government "worked" not because of the ideas that went into it but rather because of the unanticipated, stable environment which nurtured it, is a thesis a Tocquevillian could endorse. More than a century earlier the French thinker saw that the "mixed" form of government that the framers devised to contain conflict could scarcely have succeeded had conflicting class divisions truly existed in America. ${ }^{45}$ As did Tocqueville, Hartz insisted that America was held together not by its political institutions but by its widely shared values and moeurs, the emotional "habits of the heart" that had no basis in the rational political designs of 1787 . It should be recalled that the framers remained convinced that they could neither eliminate conflict nor establish consensus. Because society itself was the problem, they assumed it was more important to erect enduring political structures than to teach citizens proper political behavior. Since attitudes could not be changed, institutions must be wellgrounded.

Beard shared the framers' assumption that the spectre of class conflict haunted the Philadelphia convention, and Arendt insisted that politics and public virtue offered the only answer to the social conflicts in the New World as well as the Old. Where others saw conflict, Hartz and Tocqueville saw consensus, and in their liberal analysis the Constitution is the result, not the cause, of whatever stability and success America has enjoyed.

13 Id. at 78-79.

14 Id. at 86.

${ }^{45}$ Alexis de Tocqueville, Democracy in America 1:258-62, 316-317, 319-330 (Alfred H. Knopf, ed. 1963). 